International Journal of Current Microbiology and Applied Sciences

ISSN: 2319-7706 Volume 6 Number 1 (2017) pp. $95-99$

Journal homepage: http://www.ijcmas.com

Original Research Article

http://dx.doi.org/10.20546/ijcmas.2017.601.012

\title{
Study of Antifungal Efficiency of Curcuma zedoaria (christm.) Roscoe against Fusarium oxysporum F. Sp. Udum
}

\author{
Akhilesh Kumar Gupta ${ }^{1^{*}}$, Sandeep Chaudhary ${ }^{1}$, C.O. Samuel ${ }^{1}$ and P.P. Upadhyaya ${ }^{2}$ \\ ${ }^{1}$ Natural Fungicide Laboratory, Department of Botany, St. Andrew s College, \\ Gorakhpur, U.P. (India) \\ ${ }^{2}$ Plant pathology Laboratory, Department of Botany, D.D.U Gorakhpur University, \\ Gorakhpur, U.P. (India) \\ *Corresponding author:
}

A B S T R A C T

Keywords

Antifungal

potential, Fusarium

oxysporum,

Curcuma zedoaria,

Article Info

Accepted:

09 December 2016

Available Online:

10 January 2017
Nowadays wilt is a common disease caused by Fusarium oxysporum F. sp. Udum which causes great economic lose. Green plants are used as natural sources of treatment for several plant diseases, because they exhibit antimicrobial properties. They are also proved eco-friendly. In the present study fifteen plant extracts were tested for their antifungal potential against wilt causing fungus Fusarium oxysporum. The extract of Curcuma zedoaria (Christm.) Roscoe shows maximum inhibition.

\section{Introduction}

The wilt of pigeon pea (Cajanus cajan L.) caused by Fusarium oxysporum f.sp. udum. is one of the major limiting factor for the production of the pulse crop. It is the third most important pulse crop of world. At national level the yield loses encountered due to wilt may vary between five to ten percent (Vishwadhar and Gurha, 1998). Synthetic fungicides are currently used as primary means for the control of plant diseases despite of their harmful effects. The demand of plant based therapeutics is increasing both in developing and developed countries as they are natural products, easily available and having no harmful effects. Keeping these facts in mind the present study deals with the study of such plant extracts which are ecofriendly and can play significant role in the protection of pigeon pea from wilting.

\section{Materials and Methods}

Fifteen locally available plants viz., Allium sativumLinn., Azadirachta indica A. Juss., Achyranthus aspera Linn., Adhatoda vasica Nees, Citrus limon (L.) Burm. f., Cassia 
occidentalis Linn., Euphorbia hirtaLinn., Ricinus communis Linn., Allium cepa Linn., Curcuma domestica Valet,Curcuma zedoaria (Christm.) Roscoe, Oxalis curniculata Linn., Cannabis sativa Linn., Datura stramonium Linn., Vernonia cinerea Schreb. were collected from Gorakhpur and adjacent districts and brought into the lab for the preparation of extract.

\section{Preparation of Extracts}

$100 \mathrm{gm}$ of fresh disease free plants samples were taken and washed thoroughly with tap water to clean dust particles. After washing with tap water samples were washed with $4 \%$ sodium hypochlorite solution and finally with sterile distilled water three time, air dried and then ground with the help of sterile pestle and mortar. Extracts were filtered through double layered cheese cloth. Extracts were stored aseptically in airtight bottles and served as mother extract.

\section{Test Fungus}

The fungal strain of Fusarium oxysporumf. sp. Udum was obtained from the Microbial Type Culture (MTCC), Chandigarh (India Collection). The culture was maintained on PDA medium, which was served as the test fungi for antifungal activity.

\section{Antifungal Activity Assay of extract}

The prepared plant extract was screened against test fungus by using poisoned food technique.PDA medium was prepared and antibiotic was added to the medium at the rate of $30 \mathrm{mg} /$ litre and mixed thoroughly (Gupta and Banerjee, 1970). The autoclaved PDA medium was poured in pre-sterilised Petri plates (17ml each).

In treatment sets the required amount of plant extracts were added and allow to solidify.
Simultaneously in control sets same amount of sterile distilled water is added. After solidification of medium, five $\mathrm{mm}$ disc of seven day old culture were inoculated aseptically. Triplicate sets of petriplates were incubated at $28 \pm 2{ }^{\circ} \mathrm{C}$ for six days and observation were recorded on seventh day. The radial mycelial Growth of fungus is recorded on seventh day. The fungitoxicity of extracts was calculated in terms of percent inhibition of mycelia growth by using the formula: (Singh and Tripathi, 1999).

Percent inhibition of mycelial growth = $\frac{\mathrm{dc}-\mathrm{dt}}{\mathrm{dc}} \times 100$

Where, $\mathrm{dc}=$ Average increase in mycelia growth in control.

$\mathrm{dt}=$ Average increase in mycelia growth in treatment.

\section{Determination of Minimum Inhibitory Concentration (MIC)}

The MIC of the extract required for absolute inhibition of mycelial growth of the test fungus, Fusarium oxysporum f. sp. udumwas determined by the Poisoned Food Technique. The extract of Curcuma zedoaria(Christm.) Roscoewas prepared as described previously. Requisite amounts of the prepared extract were added to pre-sterilized Petri plates containing $17 \mathrm{ml}$ of molten PDA medium. Now 1, 0.9, 0.8, 0.7, 0.6, 0.5, 0.4, 0.3, 0.2, and $0.1 \mathrm{ml}$ of the extract is added to the medium. The contents of the plates were agitated in a circular mode to mix the extract in the medium evenly. In control sets, the same amount of sterilized distilled water was used in place of the extract. The assay plates were incubated for six days at $28 \pm 2^{\circ} \mathrm{C}$. The observations were recorded on the seventh day in terms of the percent inhibition of mycelial growth and data presented in Table: 
(2) are based on the averages of all the replications.

\section{Result and Discussion}

Antifungal activity was evaluated by poisoned food technique (Grover and Moore, 1962; Mishra \& Tiwari, 1992; Nene and Thapliyal, 2000). The results were recorded in Table No-
1. The result revealed that out of 15 plants the extract of Curcuma zedoariashows maximum inhibition (100\%), followed byAzadirachta indica A. Juss. (81\%), Allium cepa Linn (68\%).The active plant extract of Curcuma zedoaria was subjected for MIC. The results were recorded in table 2 . The $0.6 \mathrm{ml}$ of plant extract inhibits the mycelia growth of test fungus.

Table.1

\begin{tabular}{|c|l|c|c|}
\hline \multicolumn{3}{|c|}{ Table 1 } \\
\hline \multirow{2}{*}{ Sl. No. } & \multicolumn{1}{|c|}{ Plant Species } & Family & $\begin{array}{c}\text { Mycelial inhibition } \\
(\%)\end{array}$ \\
\hline 1 & Allium sativum Linn. & Liliaceae & 58 \\
\hline 2 & Azadirachta indica A. Juss. & Meliaceae & 81 \\
\hline 3 & Achyranthus aspera Linn. & Amranthaceae & 62 \\
\hline 4 & Adhatoda vasica Nees & Acanthaceae & 57 \\
\hline 5 & Citrus limon (L.) Burm. f. & Rutaceae & 26 \\
\hline 6 & Cassia occidentalis Linn. & Caesalpinaceae & 51 \\
\hline 7 & Euphorbia hirta (L)Millsp. & Euphorbiaceae & 58.86 \\
\hline 8 & Riccinus communis Linn. & Euphorbiaceae & 62 \\
\hline 9 & Allium cepa Linn & Liliaceae & 68.00 \\
\hline 10 & Curcuma domestica Valet & Zingiberaceae & 41 \\
\hline 11 & Curcuma zedoaria (Christm.) Roscoe & Zingiberaceae & 100 \\
\hline 12 & Oxalis curniculata Linn. & Oxalidaceae & 50 \\
\hline 13 & Cannabis sativa Linn & Canabinaceae & 46 \\
\hline 14 & Datura stramonium Linn & Solanaceae & 53 \\
\hline 15 & Vernonia cinerea Schreb & Asteraceae & 39 \\
\hline
\end{tabular}

Table.2

\begin{tabular}{|c|c|}
\hline \multicolumn{2}{|c|}{ Table 2 } \\
\hline \multicolumn{2}{|c|}{ Determination of Minimum Inhibitory Concentration (MIC) } \\
\hline Concentration of extract (ml) & Inhibition of Mycelial growth (\%) \\
\hline 0.1 & 12 \\
\hline 0.2 & 23 \\
\hline 0.3 & 36 \\
\hline 0.4 & 46 \\
\hline 0.5 & 93 \\
\hline 0.6 & 100 \\
\hline 0.7 & 100 \\
\hline 0.8 & 100 \\
\hline 0.9 & 100 \\
\hline 1.0 & 100 \\
\hline
\end{tabular}




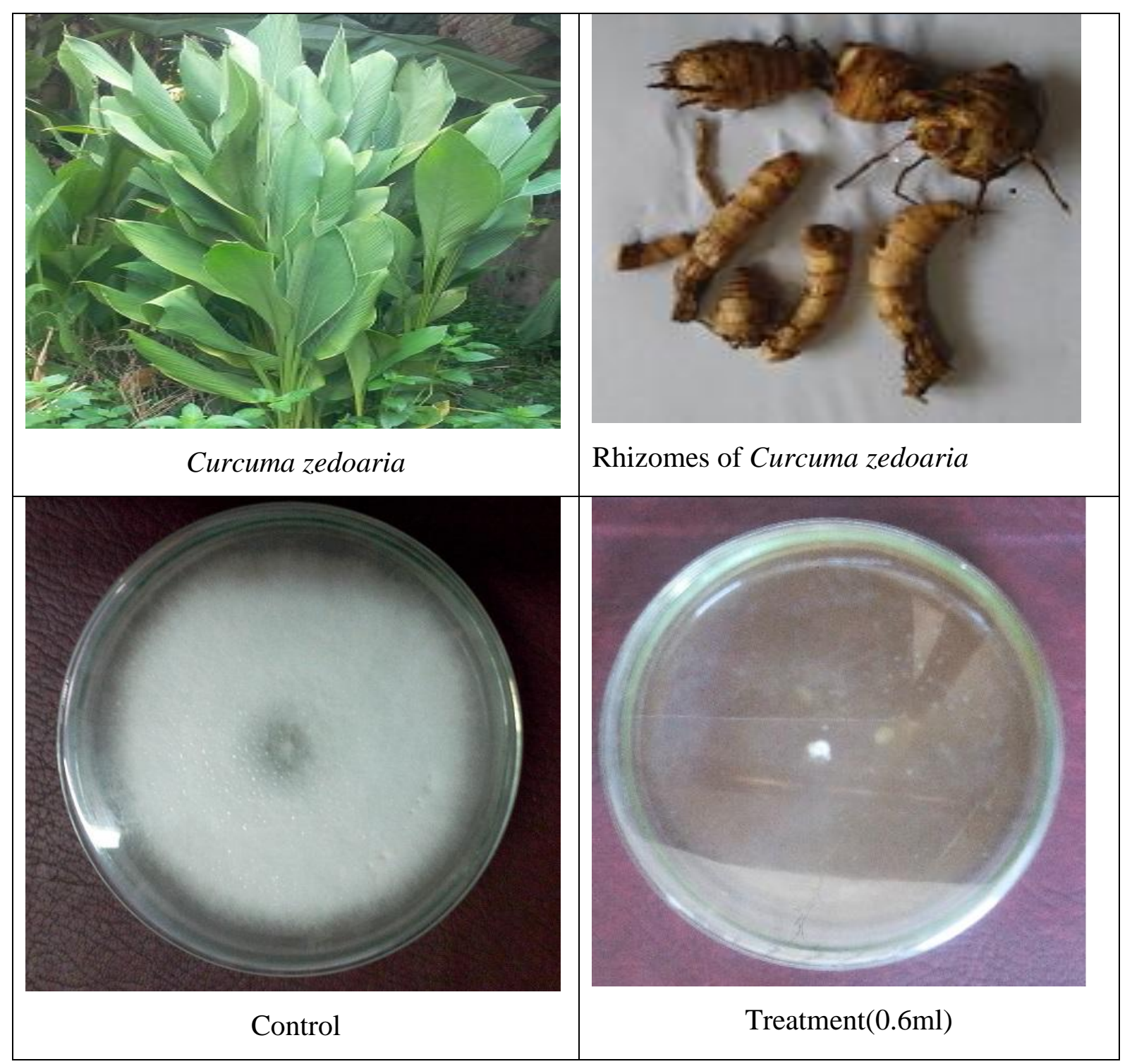

In recent past to control plant disease several types of synthetic fungicides have been used. The uncontrolled use of synthetic fungicide develops several problems in host plant as well as on non-target organisms. Many agriculturally important pesticides have been banned by World Health Organization (WHO) due to their wide range of toxicity against non-target organisms including humans. Many of them are known to cause pollution problems (Barnard et al., 1997). Due to adverse effect of synthetic fungicides on host and non-target organisms there is pressing need of development of alternative fungicides, which should be eco-friendly,less or no harmful and have no side effects on the host and other organisms.

The use of plant extracts in the treatment of diseases caused by various bacteria, viruses and fungi have been reported. Fungitoxic properties of plant extracts are widely recognized (Bylka et al., 2004; Kosalec et al., 2005; Natarajan et al., 2003).

In present investigation the extracts of fifteen plants were evaluated for their antifungal activity and the result shows that extract of 
Curcuma zedoaria (Christm.) Roscoeshows maximum inhibition (100\%), followed byAzadirachta indica. A Juss. $(81 \%)$ and Allium cepa Linn (68\%). The extract of more than 10 plants shows $50 \%$ or above inhibition in mycelial growth. The present study can play important role in crop protection by developing plant based fungicides which are natural, biodegradable, non-toxic, nonpollutive and eco-friendly.

\section{References}

Barnard, C., Padgitt, M. and Uri, N.D. 1997. Pesticide use and its measurement. Int. Pest Control, 39:161-164.

Bylka, W., Szaufer-Hajdrych, M., Matalawskan, I., and Goslinka, O. 2004. Antimicrobial activity of isocytisoside and extracts of Aquilegia vulgaris L. Lett. Appl. Microbiol., 39: 93 - 97.

Grover, R.K. and Moore, J.D. 1962. Toximetric studies of fungicides against brown rot organisms, Sclerotia fructicola and S. laxa. Phytopathol., 52: 876-880.

Gupta, S. and A.B. Banerjee. 1970. A rapid method of screening antifungal antibiotic producing plants. Ind. $J$. Exp. Biol., 8: 148-149.
Kosalec, I., Pepeljnjak, S., and Kustrak, D. 2005. Fungitoxic activity of fluid extract and essential oil from anise fruits (Pimpinellaanisum L., apiaceae). ActaPharmaceutica, 55(4): 377 - 85.

Mishra, M. and Tiwari, S.N. 1992. Toxicity of Polyalthia longifolia against fungal pathogens of rice. Indian Phytopath., 45: 56-61.

Natarajan, V., Venugopal, P. \& Menon, T. 2003. Effect of Azadirachta indica (Neem) on the growth pattern of dermatophytes. Indian J. Med. Microbiol., 21: 98 - 101.

Nene, Y., Thapilyal, L. 2002. Poisoned food technique of fungicides in plant disease control (3rd eds). Oxford and IBH Publishing Company, New Delhi.

Singh, J. and Tripathi, N.N. 1999. Inhibition of storage fungi of black gram (Vigna mungo) by some essential oils. Flavour and Fragrance J., 14: 1-4.

Vishwadhar and Gurha. 1998. Integrated management of chick pea disease. Integrated pest and disease management. Rajeeve, K., Upadhyay, K. G., Mukerji, B. P.,Chamola and Dubey, O. P.(eds.) APH publishing Co., New Delhi.(india) p.249.

\section{How to cite this article:}

Akhilesh Kumar Gupta, Sandeep Chaudhary, C.O. Samuel and P.P. Upadhyaya. 2017. Study of Antifungal Efficiency of Curcuma zedoaria (christm.) Roscoe against Fusarium oxysporum F. Sp. Udum. Int.J.Curr.Microbiol.App.Sci. 6(1): 95-99. doi: http://dx.doi.org/10.20546/ijcmas.2017.601.012 